\title{
RADIOLOGICAL STUDY OF CHONDRODYSPLASIA FETALIS IN PIGS
}

\section{J. KAMAN, Z. ZERT and J. DRABBEK}

Department of Pathological Morpholozy and Parasitolosy; Department of Surgery and Orthopedy; Department of Prophylaxis of Pig Diseases, Animal Breeding and Zoohygiene, University of Veterinary Seience, 61242 Brno

Received Juby 14, 1988

Alratruet

K a $\mathbf{m}$ a n J., Z. Z e r t, J. D r á b e k: Radiological Study of the Chondrodyplasia Fetalis in Pigs. Acta vet. Brno 58, 1989 : 323-343.

Six pigs weighing $20-30 \mathrm{~kg}$ with various degrees of motility and posture disorders from a stock exhibiting mass incidence of chondrodysplasia fetalis (CHDF), and two healthy controls of similar weight were investigated in our radiological study of this disease. A slight degree of CHDF can hardly be radiologically diagnosed without sufficient practice or comparison with controls. A more severe degree of CHDF was characteristic to such an extent that it should not be mistaken for another disease. In spite of that some structures in radiographs were identified only after a comparison was made with pathological anatomical and osteological preparations from the X-rayed animals.

Overall skeleton mineralization in radiographs did not substantially differ from the controls. Among the most striking symptoms of CHDF were deformation of growth plates and a varying extent of their premature closure, together with the cessation of the longitudinal growth of long bones. In particular, the shortening affected the humerus. femur, tibia and metapodialia. Epiphyses were greatly enlarged and deformed, which caused severe articular incongruencies with corresponding motility disturbances. Serious hip joint dysplasia was frequent. Premature closure of individual acetabular growth plates taking place at different times results in pelvic asymmetry of various proportions. Because we were able to demonstrate symptoms of CHDF in limb bones only, we call the disease chondrodysplasia fetalis disproporcionalis.

Radiology has demonstrated its usefulness as a quick, simple and effective method, allowing early diagnosis of CHDF at the time when it cannot be identified by adspection or clinical examination.

Development, anomaly, osteolozy, arthrolosy, dysplasia coxae, growth and motility disturbances, pathology, heredity, growth plates, articular incongruency

Chondrodysplasia fetalis is considered to be one of the most frequent hereditary disturbances of skeletal development in domestic animals ( $\mathrm{N} \mathrm{a} \mathrm{c} \mathrm{h} \mathrm{t} \mathrm{s} \mathrm{h} \mathrm{e} \mathrm{i} \mathrm{m} \mathrm{1940).} \mathrm{As} \mathrm{an} \mathrm{independent}$ nosological unit it was described mainly in cattle and dogs, but also in sheep, goats, rabbits (D a e m m ri ch 1967, 1985; Há mori 1983). Nieberle and Co h r s (1970) mention the possibility of its occurrence in the domestic fowl and pigs, but without giving any concrete data or quoting any authors. Apparently the first to report the occurrence of chondrodysplastic dwarfs in pigs were $J$ e $n$ s e $n$ e $t$ a 1. (1984). They focused their attention on the identification of hereditary patterns in this disease. $\mathbf{K}$ a $\mathbf{m}$ a $\mathbf{n}$ et al. (1987) diagnosed fetal disproportional chondrodysplasia in pigs of a medium-large stock where the disease had reached mass proportions.

Being a congenital anomaly, a disease occurring in newborns, as $\mathbf{S}$ u b d e $\mathrm{n}$ et al. (1972) described it in newborn pups, it eludes detection but can be diagnosed radiologically and, later, also by adspection. While investigated relatively thoroughly in man, developmental skeletal anomalies in domestic animals have not been sufficiently described and $\mathrm{J} u \mathrm{~b} \mathrm{~b}$ et al. (1985) stress the need of detailed radiological, anatomical and histological examination of this area. Our radiological study is conceived as a contribution towards this goal. 


\section{Materials and Methods}

For the radiological study, six pigs, males, and females, weighing around $20-30 \mathrm{~kg}$, with variouts degrees of motility and posture disorders and even complete collapse of motility, were chosen from a stock afflicted with fetal chondrodysplasia. The control group consisted of two clinically healthy pigs of corresponding body mass from a different stock.

The stock affected consisted of around 250 sows of ten different breeds or their combinations. Out of about 800 pigs, nearly 100 suffered from fetal chondrodysplasia, which was already observed in piglets. In juvenile pigs weighing over $20 \mathrm{~kg}$ the disease became unbearable for the problems of locomotion and posture it presented. The animals for our radiological study were selected to represent the main development stages of the disease. They were $\mathrm{X}$-rayed both alive and post mortem in the ventrodorsal, lateromedial, caudocranial and caudodorsal projections using the DUROLUX Chirana apparatus, MEDIX RAPID, Foma, films, and exposure times corresponding to the regions $\mathrm{X}$-rayed.

For better visualization of some details we used radiology of separate limbs. The structures which could not be fully and unequivocally identified in radiographs, were elucidated by comparing the radiographs with pathological anatomical and osteological preparations subsequently made from the same animals.

\section{Results}

The animals affected were characterized by their overall body structure with strikingly short limbs, relatively more developed musculature particularly in the gluteofemoral region with skinfolds, with their other dimensions, i. e. the head and overall body length, being in proportion to their age. Chondrodysplastic pigs exhibited manifested disorders of mobility, particularly in the pelvic limbs. In severe cases, the pigs were unable to stand up or maintain a standing posture.

Radiological examination confirmed by and supplemented with subsequent pathological anatomical examination corresponded with the clinical symptoms of disturbed motility as well as external symptoms of pathological anatomical anomalies. Radiographs provided convincing illustrative documents of chondrodysplasia affecting only limbs. The changes, however,were not of the same intensity when a comparison was made between pathological anatomical changes in pelvic and thoracic limbs, or between individual topographically analogous zones.

In the region of the pelvic limb, the stylopodium and in particular zeugopodium, i. e. the femur and tibia together with their corresponding joints, exhibited constant and the most serious effects of dysplasia. The lenght and width of the pelvis were not as a rule significantly affected. With the exception of the acetabulum, the changes were relatively small and to a certain extent in relation with overal the dysplastic osteochondrotic changes. This contrasted with the crural region, and in particular the tibia, which exhibited striking anomalies in the proximal metaphysis and especially epiphysis, even in otherwise fairly mild cases of chondrodysplasia.

Dysplastic changes in the pelvis were localized in the acetabular region. Our group of experimental animals comprised pigs in different stages of the disease, form very mild to the most severe; from hip joints with femur epiphysis fully inserted acetabulum to its partial or total luxation where it was dislocated completely out of the acetabulum.

Radiographs confirmed a striking agreement between an overall situation in the bones of the pelvic limb, particularly as regards tibial dysplasia, and the intensity of the diseases manifestations in the hip joint region. If the changes in the tibia were relatively small, radiographs of the hip joint region showed 
situation which was close to normal, with uniformly spherical caput femoris, fully inserted in the adequately formed fossa acetabularis. As regards the length, width and thickness of its bones, the pelvis was developed quite normally. The dynamics of dysplastic changes in the pelvis are shown in Figs. 1-6. The mildest cases of the disease (Fig. 1) were manifested in the hip bone region by a mild sometimes hardly noticeable flattening of the acetabulum and adequately caput femoris, a slight but distinct narrowing of the bright stripe in the epiphyseal plate of the caput femoris and the acetabular growth plate between the ilium and the ischium, which indicates premature ossification. Practically all of the caput femoris is inserted in the acetabulum.

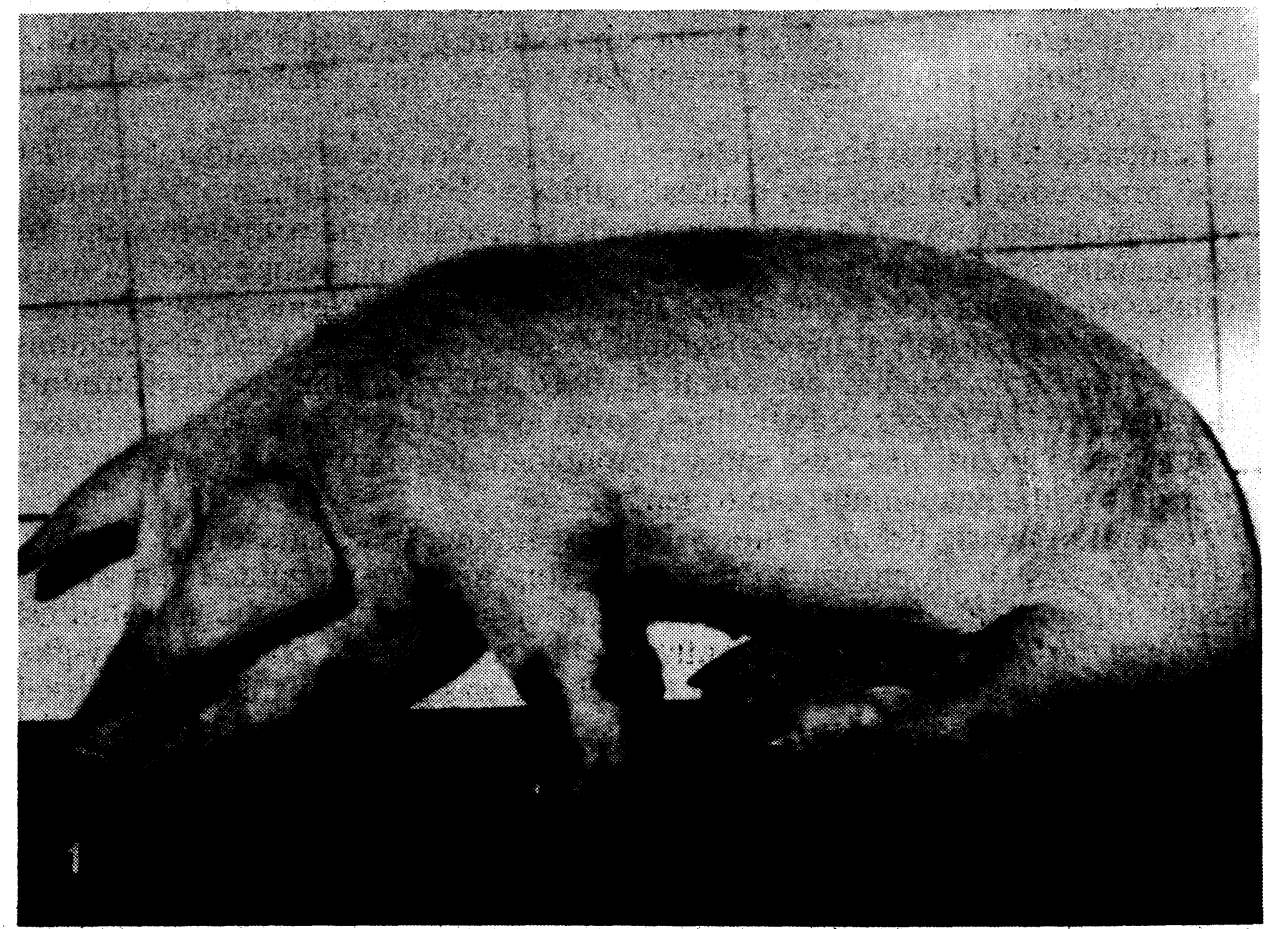

Fig. 1. Serious degree of chondrodysplasia fetalis (CHDF). Strikingly short limbs placed under the body, arched back, collapse of pelvic limbs motility.

The joint may be affected unilaterally. Fig. 2 shows a slightly affected right hip joint, which is expressed in a slight flattening and oval craniocaudal elongation of the fossa acetabularis, with an analogically shaped caput femoris. The left-side caput femoris is regular in shape but the joint space is wider.

Acetabular growth cartilage of the right acetabulum in Fig. 3 is still very prominent, which corresponds to the slightly affected tibia on the right. The distinct narrowing of the bright patch of the intra-acetabular cartilage of the left acetabulum, on the other hand, corresponds to the severe dysplasia of the proximal epiphysis of the tibia on the left. 
Fig. 4 shows a strongly asymmetric pelvis, its left half being substantially shorter than the right one. Growth cartilage between the ilium and left ischiadic acetabulum is hardly perceptible, while in the right acetabulum, growth cartilage is relatively wide. The difference between growth cartilage of the two hip joints is responsible for the difference in length between the two pelvic halves. Uniform radiodensity, merging with that of pelvic bones, with just a faint suggestion of fossa which was confirmed by a total dislocation of the caput femoris out of the acetabulum. Irregular shadows protruding from the floor of the right acetabulum point to exostotic activity. This corresponds to a partial dislocation of the right caput femoris.

Practically analogical changes were found in pig No. 5. This time, however, the right half of the pelvis was shorter and the right acetabulum changed. The most serious X-ray finding in the hip joint region of this pig was a dislocation of both femural heads completely out of the acetabulum and their severe dysplasia.

Compared to control animals, the pelvis of pig No. 6 was considerably wider in all projections and its bones noticeably thicker. The acetabulum in the ventro-dorsal projection was of a characteristically spherical shape with homogeneous radiodensity, merging with of pelvic bones, with just a faint suggestion of fossa acetabularis in the left acetabulum. In radiographs their rims have a double contour. A comparison of the radiographic finding with osteological preparations showed that both acetabula were entirely filled with new bone tissue protruding over the rim. The heads of both thigh bones are strikingly low. They are loose, unattached to the articular fossa either morphologically (enartrosis) or anatomically by means of the ligamentum capitis femoris.

Femoral dysplasia belongs among the most striking and characteristic changes. Its degree was in proportion to that of the hip joint dysplasia and an overall health impairment. In the case of mild dysplasia (Fig. 7), the longitudinal growth of the bone was not significantly affected (see controls), but chondrodysplasia was indicated by the fact that the thigh bone was generally thicker, the distal epiphysis broadened into a club-like shape, particularly in the cranio-caudal direction, characteristic gutter-shaped bent of the metaphyseal rim in the proximal direction, and severe tibial dysplasia.

In slightly severe fetal chondrodysplasia (Fig. 2, left), we find the caput femoris either still regularly shaped in analogically shaped acetabulum, or already flattened but still sufficiently inserted in the articular fossa. Distal metaphyses of both femurs are substantially broadened, the edge turned back in a gutter-shape fashion, the diaphyses shortened and epiphyses substantially enlarged.

In medium severe chondrodysplasia the most striking symptoms include heavy lateral deviations of thighbones with their heads bent outwards (coxa valga). Their considerable shortening with a strong club-shaped broadening of the distal end is connected with a total disappearance of the distal epiphyseal cartilage and considerable narrowing or even partial disappearance of the proximal epiphyseal cartilage.

Severe chondrodysplasia of the thighbone is characterized by a total or nearly total dislocation of its head out of the acetabulum. Figs. 4 and 6 present a characteristic and unmistakable picture. The shortening is most noticeable in the diaphysis. Distal metaphysis broadens suddenly and extremely, presenting a goblet-like appearance, with robustly developed distal epiphysis inserted into it, its width reaching up to $2 / 3$ of the femur. Proximal metaphysis broadens 
to a lesser extent, the collum femoris is markedly shortened and thickened.

Radiographs of the regio cruris demonstrated very impressive dysplastic changes, particularly in the tibia, which was shortened by 1/4 and thickened by $1 / 2$ compared to the controls. The fibula, on the other hand, was shortened relatively less, or not at all, frequently overlapping the tibia distally as well as proximally (Figs. 5, 6). The mataphysis and epiphysis of the tibia were extremely broadened compared with the diaphysis. The proximal broadening of the tibia was considerable. In this way the tibia acquired a very characteristic goblet shape, giving it sometimes a bouquet-like appearance in radiographs (Fig. 5). At the same time, its proximal epiphysis was heavily dysplastic.

As regards the mutual topographic relation between the tibia and the fibula, radiographs recorded a noticeable difference in chondrodysplasia fetalis individuals and pigs in the control group. The tibia and fibula cross each other at an angle which is noticeably more obtuse in CHDF than in control animals. This is of course primarily due to an anomalous broadening of the proximal metaphysis of the tibia in these animals.

Hock bones did not exhibit any striking changes. The difference between abnormal and normal tarsocrural joints is shown in Fig. 7.

Very characteristic radiographs were obtained in the case of metatarsal bones. As shown in Fig. 8, metatarsals III and IV were about 1/6 to 1/4 shorter and, more strikingly, about $1 / 3$ to $1 / 5$ thicker. Their bodies were broader at both ends, more prominently in the distal direction. Here the generally more massive heads of metatarsals were set on a bell-like broadened metaphyses. The thickening of bodies of metatarsals II and V was less conspicuous. This emphasized the sudden and intensive broadening of the most distal metaphysis with a heavily broadened epiphyseal head, which gives metatarsals II and V their characteristic drumstick shape.

The proximal phalanges of digits III and IV were of normal length or scarcely discernibly shorter, and regular in shape. They were only about $1 / 4-1 / 3$ thicker than in the controls, particularly in the base regions.

Still less significant changes or up to slight thickening were found in radiographs in the middle and particularly the distal digital segments.

Radiographically demonstrable changes to the thoracic limbs on the one hand corresponded to the pattern of motility disorders and to the osteochondrodysplastic changes in the pelvic limbs, and on the other differed from them. While the bones of the acropodium were slightly affected both in pelvic and thoracic limbs, bones of the zeugopodium of the pelvic limbs, especially the tibia, were among the most affected by dysplasia, but the analogous bones of the thoracic limbs were considerably less affected.

The shoulder blade was not very markedly affected either in its length or width, even in the most serious cases. Changes were limited to the angulus ventralis scapulae region, where the generally round circumference of the fossa glenoidalis changed to a cranio-caudal oval circumference with a hint of flattening in the articular cavity. In severe cases of fetal chondrodysplasia pathological anatomical changes are proportionally more serious and well recognisable in radiographs (Fig. 9). The whole of the distal end of the shoulder blade is strikingly cranio-caudially broadened, especially the angulus distalis scapulae. Its fossa glenoidalis is abnormally shallow or even slightly convex (Fig. 9). The tuberculum supraglenoidale and particularly the processus coracoideus are developed more markedly, already well ossified, of a corresponding radiological 
density. A brighter arch near the basis of a beak-like protrusion indicates a fairly wide apophyseal cartilage, the thin zigzaging line of increased radiological density along both sides of this apophyseal cartilage pointing to a slight exostotic growth.

The humerus was the most shortened and pathologically deformed bone, as regards both the normal humerus as well as the other of thoracic limb bones. In mildly affected animals the changes were proportionately less serious but nevertheless perceptible. The caput humeri was demostrably flatter than normal, also relatively flatter and more voluminous was the tuberculum majus. The proximal metaphysis exhibits a tendency towards dilation, its edge in the caput humeri region folding distally in a collar-like fashion and the diaphyseal region showing slight thickening of the corticalis. The distal metaphysis-epiphyseal edge, on the other hand, exhibits a tendency to bend in the proximal direction.

The described changes and tendencies towards them were strongly expressed in heavily affected individuals, as shown in Fig. 9. While femoral epiphyses were more thickened distally, the humerus had both epiphyses extremely developed and their width was up to $4.3 \mathrm{~cm}$, i. e. more than half the length of the bone. Its body was unusually short, because the whole of the bone broadened markedly in a club-like fashion from the middle towards the ends. The most characteristic feature of the CHDF in the humerus was the extremely developed and markedly flattened caput humeri, resembling the head of a toadstool. Pointing caudo-distally, it overlaps the caudal surface of the humerus to almost half way down the length of the diaphysis. The neck of the head is unusually short, thick and perpendicular to the longitudinal axis of the humerus, so that the free rim of the head all but leans against the humeral body, with only about $0.5 \mathrm{~cm}$ distance between them. Fig. 9 shows that the epiphyseal cartilage has to a large extent prematurely ossified and remained only along the metaphyseal rim. Only slightly perceptible linear brightening between the edges of the shadows of the tuberculum majus and minus humeri indicates narrowing or even disappearance of the sulcus intertubercularis. The deformation ot the humeral head, and in particular its shift towards the caudal edge of the humerus, caused also a shift in the tuberculum majus in the caudal direction. The tuberculum majus is lager and more voluminous than normal, but conspicuously lower and with a conic base. The fact that in Fig. 9 it rises slightly above the caput humeris is caused by the flattening of the head. The body of the humerus is markedly thicker (by about a third), short, the compacta thicker.

The most extensive and functionally the most serious deformations were ascertained in the distal end of the humerus. This was substantially broadened not only latero-medially but also in the cranio-caudal direction. The edge of the distal metaphysis together with the trochlea extend anomalously in the cranio-proximal direction into the fossa radialis humeri, practically overlapping all of it. But especially it propagates itself caudio-proximally into the fossa olecrani and blocks it, functioning thus as a pathological barrier to the processus anconeus (Fig. 9), limiting considerably and even totally preventing the extension of the cubital joint.

Fig. 9 also proves that forearm bones were not shortened at all or only insignificantly. Serious functional and pathological anatomical changes were only in those segments of forearm bones which constitute parts of the cubital joint. The proximal epiphysis of the radius is thinner, hypoplastic, the joint surface depressed and apparently abnormally rearranged as a result of the influence of 
the pathologically formed distal epiphysis of the humerus, markedly incongruent. Also apparent is the newly formed adaptive joint surface on the medial rim of the radial head, which is a result of the pressure stimulus of the pathologically enlarged epicondylus medialis humeri.

Instead of an arch, the incisura trochlearis ulnae forms an obtuse angle. The processus anconeus is more obtuse and radiographs show that it is stopped by a tongue-like protrusion of the humeral trochlea into the fossa olecrani, preventing the extension of the joint, and, together with the pathologically developed epicondyhus humeri medialis, preventing physiological contact of all the bones which make up the cubital joint.

The carpus as a whole as well as individual carpal bones, corresponded in shape, size and the degree of ossification to the controls in both lateral and dorso-palmar projections.

As illustrated in Fig. 10, metacarpal bones exhibited striking changes with highly characteristical shapes, just as did metatarsal boens in the pelvic limbs. The principal metacarpals (III and IV) were about $1 / 5$ shorter and and 1/6 thicker than in the controls. Radiographs show that while metacarpal bases including their articulation with the carpals are regularly formed, the distal metaphyses suddenly and sharply widen, typically in a bell-like shape, with analogically enlarged epiphyses resting against them. Similarly matacarpals II and V. Their distal ends, like in the pelvic limbs, broaden more suddenly and intensively than the principal metacarpals, with their heads nearly twice as wide as their bodies, and of a strikingly club-like shape.

Radiographs of the digits of thoracic limbs as well as the checks on bone preparations showed a situation which can be considered normal from the anatomical point of view. Both principal digits, as shown in Fig. 10, are of the same length and size; $i$. e. they are symmetrical and it can be assumed that the pig could walk on both of the digits before its motility problems culminated. We are stressing this fact because there has recently been some tendencies to claim that the IIIrd digit of the pig is physiologically shorter and thinner than the IVth digit.

\section{Discussion}

In the previous paper ( $\mathrm{Ka} \mathrm{m}$ a $\mathrm{n}$ et al. 1987) we already pointed to the ambiguities in the literature concerning the name of the disease we were describing. Of a number of synonyms we preferred the name chondrodysplasia fetalis ( $\mathrm{J} \mathrm{u} \mathrm{b} \mathrm{b}$ et al. 1985), which describes the health disorder in question with sufficient accuracy and is the most appropriate one.

Radiology was used to diagnose chondrodysplasia in dogs by $\mathrm{M}$ a th e r (1956), A l m 1 of (1961), S u b d e n et al. (1972), F l e t ch et. al. (1973); in sheep by W r a y (1971); in pigs by J e n s e $n$ et al. (1984). None of these was conceived as a thorough radiological study but as a diagnosis of chondrodysplasia in random or intentionally followed cases. This also explains the briefness of their X-ray findings. M a th e r (1956) described eight-week old litter of Scottish terrier, where four out of six pups adopted a ,turtle“ posture, unable to walk. In spite of a heavy motility disturbance, X-ray descriptions speak only obout thicker and shorter long bones and poorly developed epi- and metaphyses compared to normal. S u b d e $n$ et al. (1972) described the chondrodysplastic syndrome in dogs of the breed Alaskan Malamute. As a characteristic 
finding in radiographs they considered broad and irregular epiphyseal cartilage, which is in basic contradiction to our own findings in pigs where, on the contrary, epiphyseal cartilage was markedly thinner, the epiphyses enormously developed. The premature ossification of cartilage prematurely terminated the growth of long bones, which appeared conspicuously shorter. It, however, remains unclear why some of the long bones are so drastically shortened (femur, humerus) and other less or not at all (ulna).

Valuable results were presented by the same authors in their next study (F1 e t c h et al. 1973). They confirmed chondrodysplasia in further 70 dogs of the same breed. Besides a radiological diagnosis they also carried out some other examinations, focusing in particular on levels of minerals and vitamin D. They found no deviations from the normal, and, what is more, their increased dietary doses failed to improve the conditions of the sick animals, which corresponds with our own findings ( $\mathrm{K}$ a $\mathrm{m}$ a $\mathrm{n}$ et al. 1987) in pigs. It follows from this that biochemical diagnosis of chondrodysplasia is questionable.

In young pups, diagnosis of chondrodysplasia fetalis by inspection is difficult (F 1 e t c h et al. 1973) but feasible in individuals older than 3 months. Not only can we confirm this conclusion but we could also add that in large-size stocks identification of affected piglets is even more difficult; a possible solution at this stage is offered by radiological diagnosis. In piglets older than 2 or 3 months with higher weight and more pronounced motility disorders, sick animals can easily be detected by means of adspection and the diagnosis can reliably be confirmed radiologically.

In their genetical study on the incidence and more of propagation of the chondrodysplastic syndrome in dogs of the breed Alaskan Malamute, S u b d e n et al. (1973) concluded that the macrophenotypic effect ot the chondrodysplastic syndrome was reminiscent of the morphology of rachitis, differring from it clinically and radiologically, which allows the two to be distinguished. The relation between this developmental disturbance and endochondral ossification can be radiologically documented. In spite of individual variations, the most serious and characteristic effects were recorded by these authors (F le t ch et al. 1973) in the distal epiphyseal cartilage of the ulna. This is in complete disagreement with our findings in pigs.

In the literature we never met-with a specialized deeper radiological study of chondrodysplasia in the pig or in any other species, a study that would not only diagnose a developmental disorder but would also in greater detail document and radiologically identify recorded phenomena with the aim of elucidating the mechanism of the genesis of this anomaly, which is what we are attempting in our paper.

$\mathrm{J}$ e $\mathrm{n}$ s e $\mathrm{n}$ et al. (1984) did use radiology in his study into chondrodysplasia in pigs, his radiological findings, howerer, are confined to five sentences only. If we take into account isolated limbs were X-rayed only, it is thus understandable that the authors were unable to express an opinion on some of the significant morphological and functional changes, particularly in the pelvic region.

Radiology represents an easy, quick, illustrative and reliable intravital diagnostic method allowing identification of fetal chondrodysplastic changes.

A mild degree of chondrodysplasia in the pig can be reliably diagnosed only by making a comparison with control material or on the basis of sufficiently specific experience. Marked and heavy chondrodysplasia is so characteristic radiologically that its diagnosis should be unequivocal and should present no 
problems. In spite of that differential diagnosis will have to take into consideration rachitis, congenital dysplasia of the hip joint, the arthrosis of the articulatio coxae, femur subluxation and luxation, interruptio ligamenti capitis femoris, epiphysiolysis capitis femoris, dystrophic and arthrotic changes in the knee joint, especially in the proximal epiphysis of the tibia, and in the elbow joint.

We classify chondrodysplasia in pigs we investigated radiologically as disproportional, affecting long bones of the limbs of the endochondral type. The interstitial growth of the bone in the longitudinal direction is disturbed or halted, but the perichondrial appositional broadening remains unchanged. A constant accompanying symptom in all radiographs of bones affected by chondrodysplasia is therefore a gradual and even total immature closure of growth cartilage, in particular epiphyseal cartilage, discernible usually only as lineae epiphysiales, and the cessation of growth of the bones affected.

As a basis for an objective evaluation of the state of growth cartilage in chondrodysplasia fetalis we used radiological diagnosis of epiphyses and apophyses of growth plates and their ossification in the limbs of pigs from neonates to three-year old individuals ( $\mathrm{S} \mathrm{z}$ e $\mathrm{m}$ e s 1962), in particular the X-ray study of the closure of epi- and apophyseal growth cartilage in pigs of the breed German Landrace aged 14 days to 4 years ( $W$ e is s 1972), and to a certain extent also a radiological study of the appendicular skeleton of the pig in the fetal and early postnatal periods ( $\mathrm{W}$ r a t h a 11 et al. 1974).

Depending on the seriousness of the disease in different stages, long bones of the limbs are not only shorter but also thicker compared to controls, their epiphyses broader, extended and contrasting with short diaphyses. Similar findings are reported by $\mathrm{D}$ a e $\mathrm{m} \mathrm{m} \mathrm{ri} \mathrm{ch} \mathrm{(1967)} \mathrm{in} \mathrm{dogs,} \mathrm{while} \mathrm{"normal,} \mathrm{but} \mathrm{enlarged}$ epiphyses " in chondrodysplasia fetalis of the dexter type are described in the cattle by J u b b, Kennedy and Palmer (1985). Mather (1956), on the other hand, mentions poorly developed epiphyses and metaphyses when evaluating radiographs of eight-week old pups suffering from chondrodysplasia. From our results it follows that pathological anatomical changes are less unambiguous. Heavily enlarged distal epiphyses were found in the humerus and femur, and in metacarpals and metatarsals. Together with a toadstool shape of the caput humeri and the caput femoris positioned nearly perpencicular to the longitudinal axis of the bone, heavily dysplastic acetabulum, club-like broadening of the metacarpals and metatarsals, they belong among the most characteristic symptoms of chondrodysplasia in the pig. On the other hand we found a marked to heavy dysplasia and hypoplasia in the proximal epiphysis of the tibia with a simultaneuous considerable broadening of its metaphysis. The above discrepancies do probably not result from real differences but from the fact that heterogeneous sources were used, and that a comparison was therefore made of incomparable material.

A constant finding in radiographs of dysplastic long bones is a characteristic gutter-like bending of the free edge of enlarged metaphyses: a phenomenon of which we found no mention in the literature. As we state in the results, the epiphyseal cartilage, usually formed (or deformed) to resemble a bowl, first closes at its „bottom “ and closes last at the edge, where the bone growth is maintained to various extent. Due to the deformation of the epiphyseal cartilage no growth along the longitudinal direction takes place but only along the transversal, making the bone thicker and extending not only the epiphysis but also the metaphysis, whose free rim bends in a proximal direction. 
We would like to stress the fact that the skeleton mineralization of the pigs examined was generally good and did not differ substantially from the controls. This seems to be in disagreement with several forms of chondrodysplasia in dogs, in particular the dysplasia epiphysialis multiplex, a pseudochondroplastic dysplasia where not only is the development of ossification centres delayed, but the centres consist of multiple dot-like ossifications, which disappear and at the age of about 5 months are incorporated in normal ossification centres ( $\mathrm{J} \mathrm{u} \mathrm{b} \mathrm{b}$ et al. 1985). Individual forms of chondrodysplasia should not, however, be interchanged or mechanically applied from one species to another. Further corrections are possible only on the basis of further research. This is evident, e. g., from the attitude of $\mathrm{D}$ a e $\mathrm{m} \mathrm{m} \mathrm{r} \mathrm{i} \mathrm{c} \mathrm{h} \mathrm{(1967),} \mathrm{who} \mathrm{described} \mathrm{dysplastic}$ changes in the dog as chondrodystrophy and later (D a e m m r i ch 1985), on the basis of new information in the field, he described the same finding as chondrodysplasia.

As regards functional significance and difficulties in an objective evaluation of radiographs, the regions of the elbow joint, pelvis and in particular that of the hip joint and to a certain extent also knee joints proved the most demanding. There is no paper in available literature to which references could be made. Only $\mathrm{D}$ a e m m r i c h (1985) reports that in chondrodysplastic cattle the pelvis is narrow and short. Such a finding could be obtained under the condition that growth cartilage of the pelvis is bilaterally, uniformly and, most importantly, at the same point in their development, afficted with premature ossification.

From our findings it follows that immature closure of acetabular growth plates in CHDF takes place very often differently in individual places. This results in various anomalies in the formation of the pelvis. As can be seen, e. g., in Figs. 5 and 6, a premature closure of the growth cartilage between the iliac bone and the ischium, with the growth cartilage between the pubis and the iliac bone still functional, the pelvic bone deviated laterally and a one-sided (asymmetric) extension of the pelvic inlet occurred. In another case (Fig. 4), on the contrary, there was a time lag between closures of the growth cartilage between the iliac bone and the ischium in the left compared to the right halves of the pelvis, which resulted in its one-sided asymmetric shortening.

To identify some dubious radiographically visualized structures in CHDF, particularly in the region of the elbow, hip and knee joints, we shall need some practical training, suitable corresponding documentation or a possibility of subsequent checks, a detailed pathological anatomical autopsy of the pertinent regions or corresponding osteological preparations. For this reason special attention was paid to the pertinent documentation and its description. Radiological findings were made more accurate by means of an autopsy and osteological preparations from X-rayed individuals. 


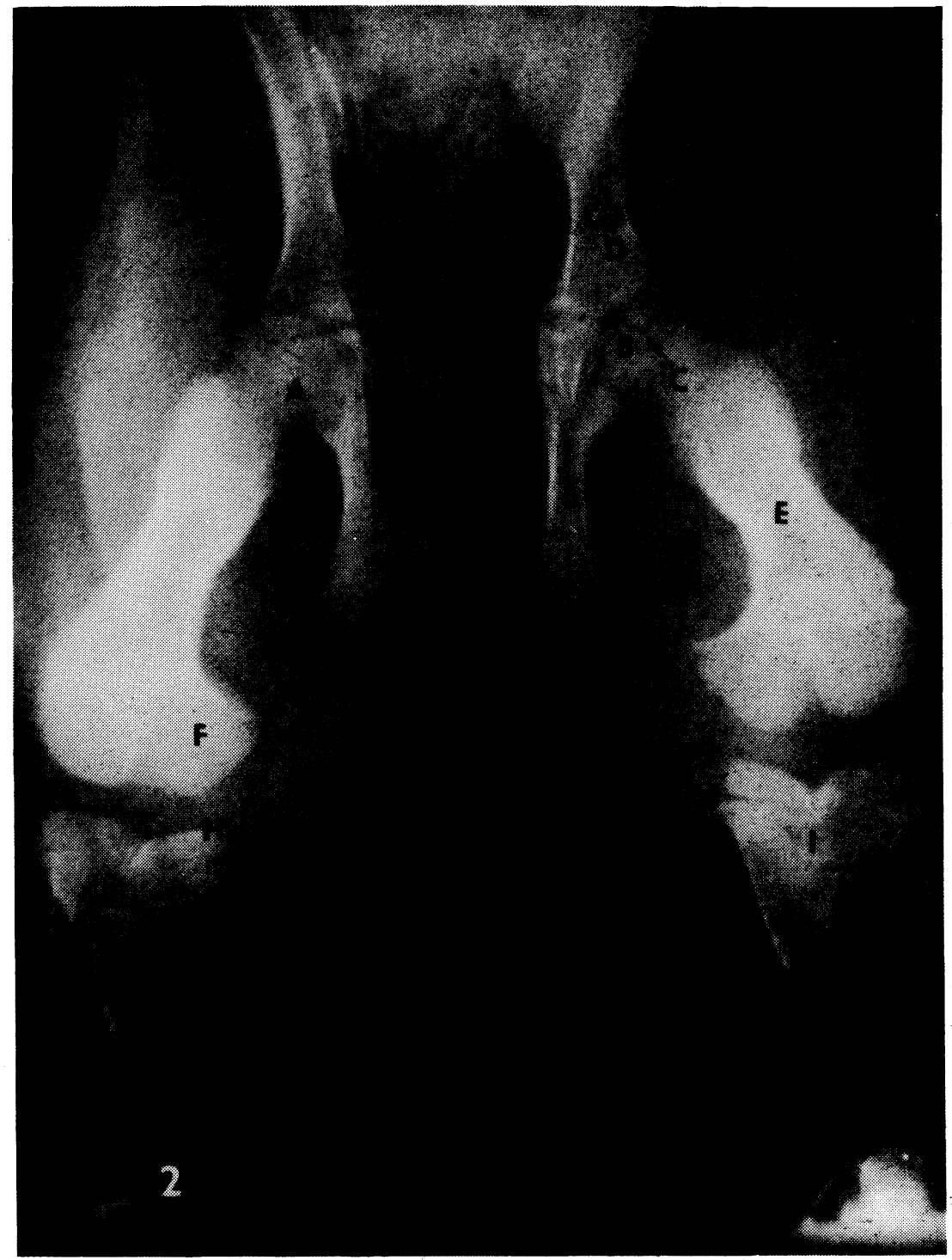

Fig. 2. Radiograph of the pelvic region and proximal section of pelvic limbs in a pig with a milder case of CHDF.

Ventrodorsal projection.

A - caput femoris dextrum, slightly flattened, B - regularly formed caput femoris sinistrum, C cartilago epiphysialis proximalis closed in the right femur, distal epiphyseal cartilage in both femurs also closed. D - cartilago acetabularis, $E$ - shortened left femur corresponds to enlarged articulation space in the knee joint, F - slightly enlarged distal epiphysis of the femur, $\mathbf{G}$ - remaining part of cartilago epiphysialis distalis and gutter-like bending of the metaphyseal rim, $\mathrm{H} \mathrm{-}$ hypoplastic condyles of the tibia, I - cone-shaped proximal epiphysis of the tibia, $\mathbf{J}$ - markedly narrowed cartilago epiphysialis, $\mathbf{K}$ - remaining part of epiphysialis proximalis of the tibia, $\mathrm{L}-$ markedly narrowed cartilago apophysialis tuberis ischiadici with left half of the pelvis slightly shortened. 


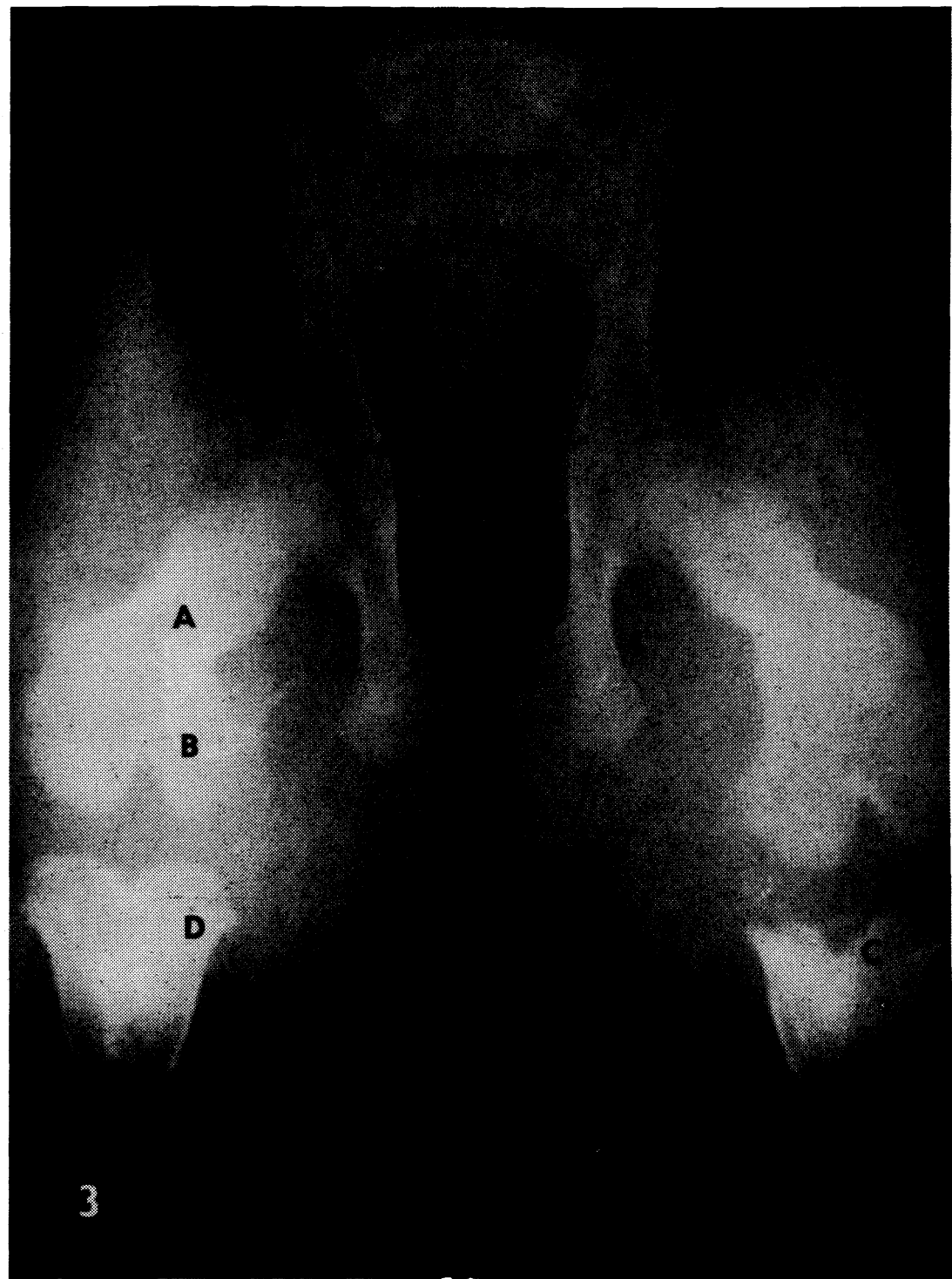

Fig. 3. Radiograph of pelvic and femoral regions of pig with more serious CHDF. Ventrodorsal projection. Acetabular growth cartilage on the left clearly thinner than on the right. A Markedly shorter right femur, B - markedly enlarged epiphysis, C - heavily hypoplastic epiphysis proximalis tibiae, hardly perceptible brighter line in its cartilago epiphysialis, D - marked brightening between less affected epicondyli tibiae and the epiphysis itself, cartilago epiphysialis nearly completely closed. 


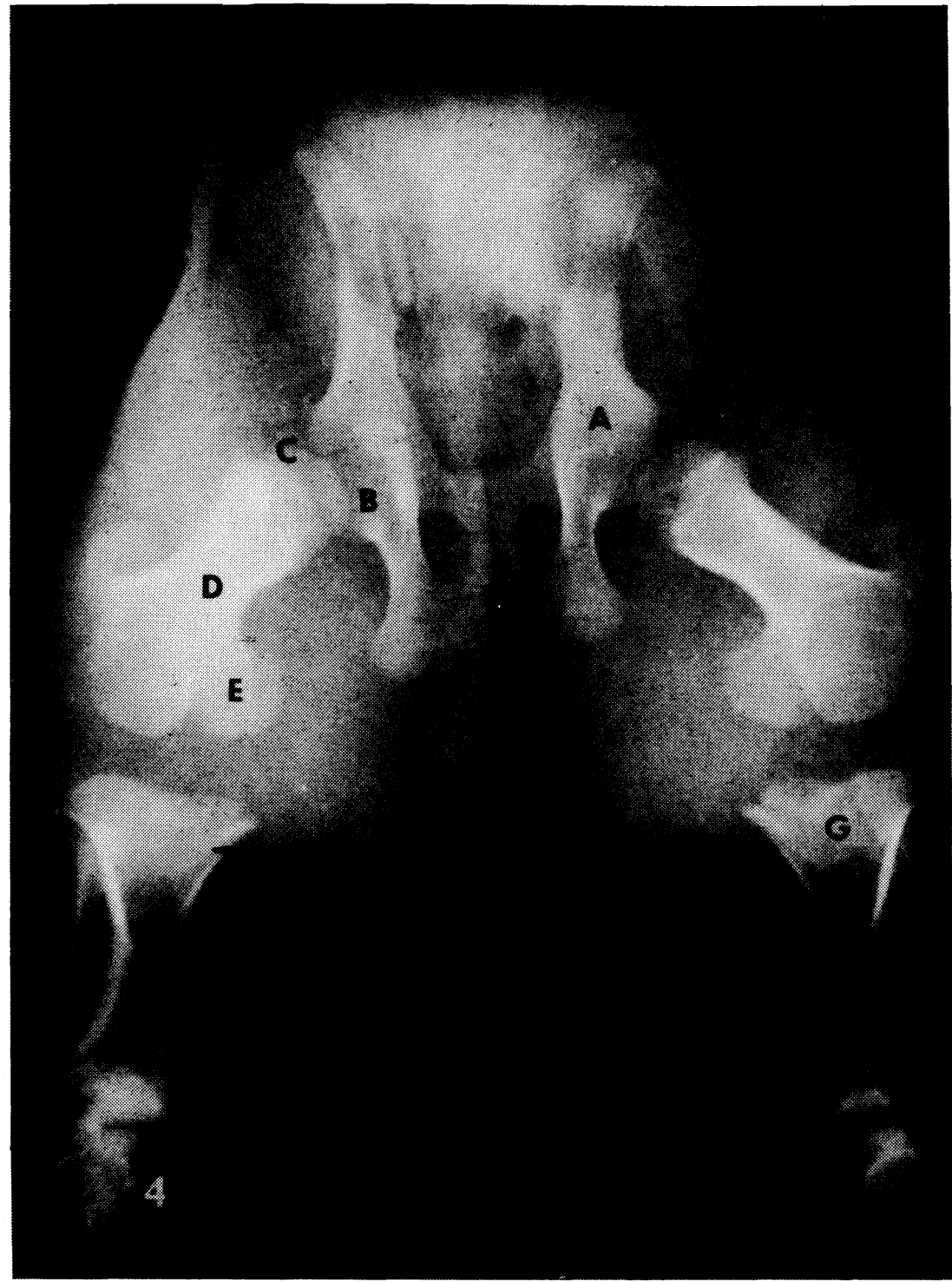

Fig. 4. Radiograph of the pelvic region and proximal part of pelvic limbs of a pig with serious form of CHDF. Ventrodorsal projection. Strong pelvic asymmetry, left ilioischiadic growth cartilage nearly completely closed, left half of pelvis substantially shorter, total luxation of the left femur, nearly total luxation of the right femur, both femurs and tibias substantially shortened, epiphyseal cartilage nearly or completely closed.

A - acetabulum sinistrum with predominantly homogenous density, B - acetabulum dextrum with brightening in the articular fossa and growth plates, $\mathrm{C}$ - thinner and slightly flattened caput femoris dextrum, partially inserted in acetabulum, D - extremely shortened diaphysis, E - greatly enlarged distal epiphysis and patella (F), G - heavily dysplastic proximal epiphysis of tibia, H - epiphyseal cartilage has all but disappeared, on the epiphyseal as well as metaphyseal sides lined with linear densification of shadow of the surrounding primarily ossifying tissue. 


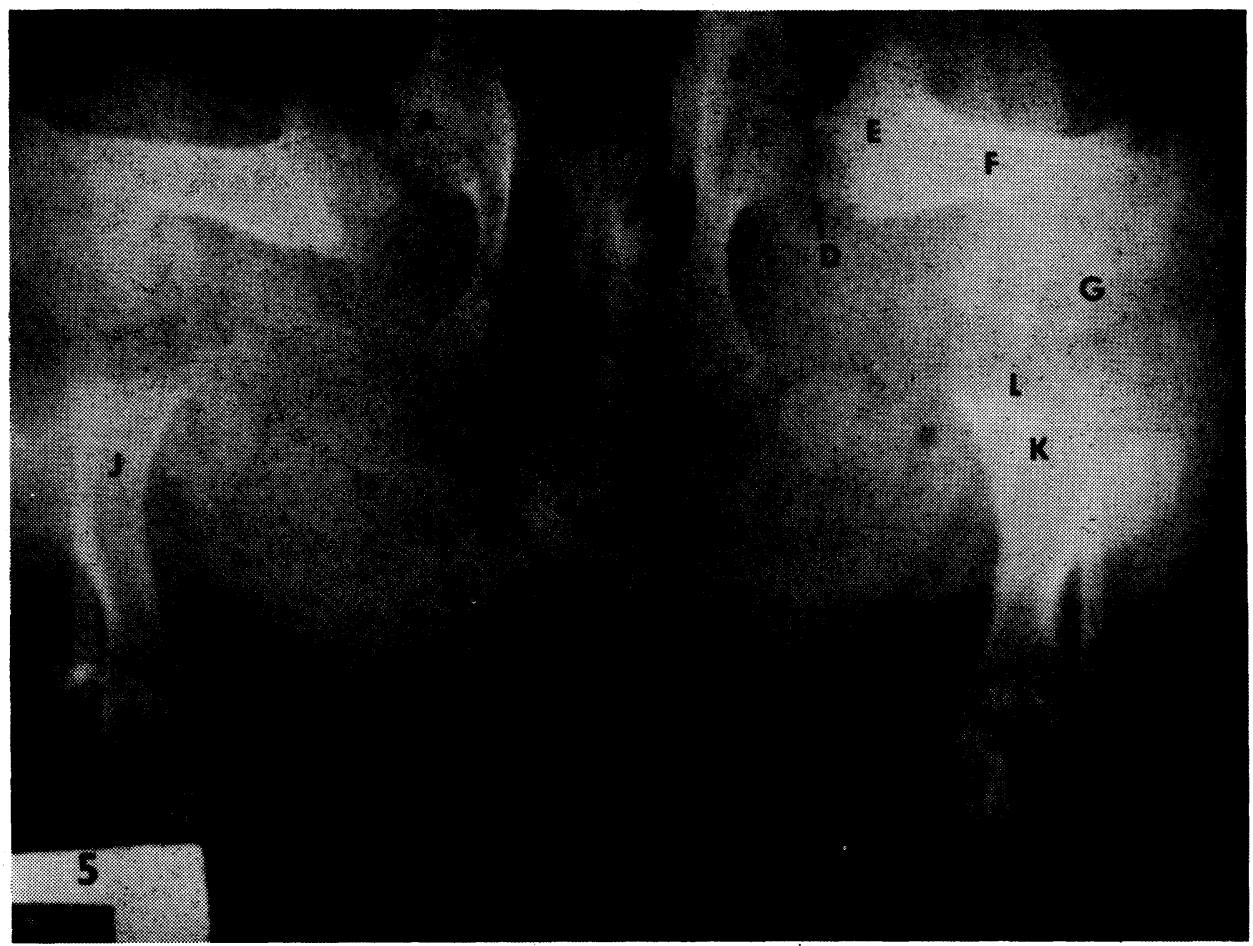

Fig. 5. Radiograph of pelvic region and limbs of a pig with very serious CHDF, characterized by complete collapse of motility and standing posture. Ventrodorsal projection. Pelvic asymmetry, its right half markedly shortened, closure of the ilioischiadic growth cartilage, round acetabulum with homogenous X-ray density. Oval left acetabulum with growth cartilages preserved. Femoral and crural bones heavily dysplastic and extremely short.

A - Acetabulum dextrum, B - brightening of the acetabular growth cartilage, C - strongly hypoplastic caput femoris, its surface uneven, D - markedly dysplastic trochanter major, E cartilago epiphysialis, F - left femur, nearly imperceptible diaphysis immediately broadens markedly into metaphyses, $\mathbf{G}$ - extremely enlarged distal epiphysis, $\mathbf{H}$ - patella, J - greatly broadened proximal metaphysis of the tibia, $\mathbf{K}$ - conic epiphysis, highly hypoplastic, pressed into the metaphysis with very uneven and incongruent facies articularis $(\mathrm{L}), \mathbf{M}$ - crater-like excavation of the distal articular surface of the tibia. 


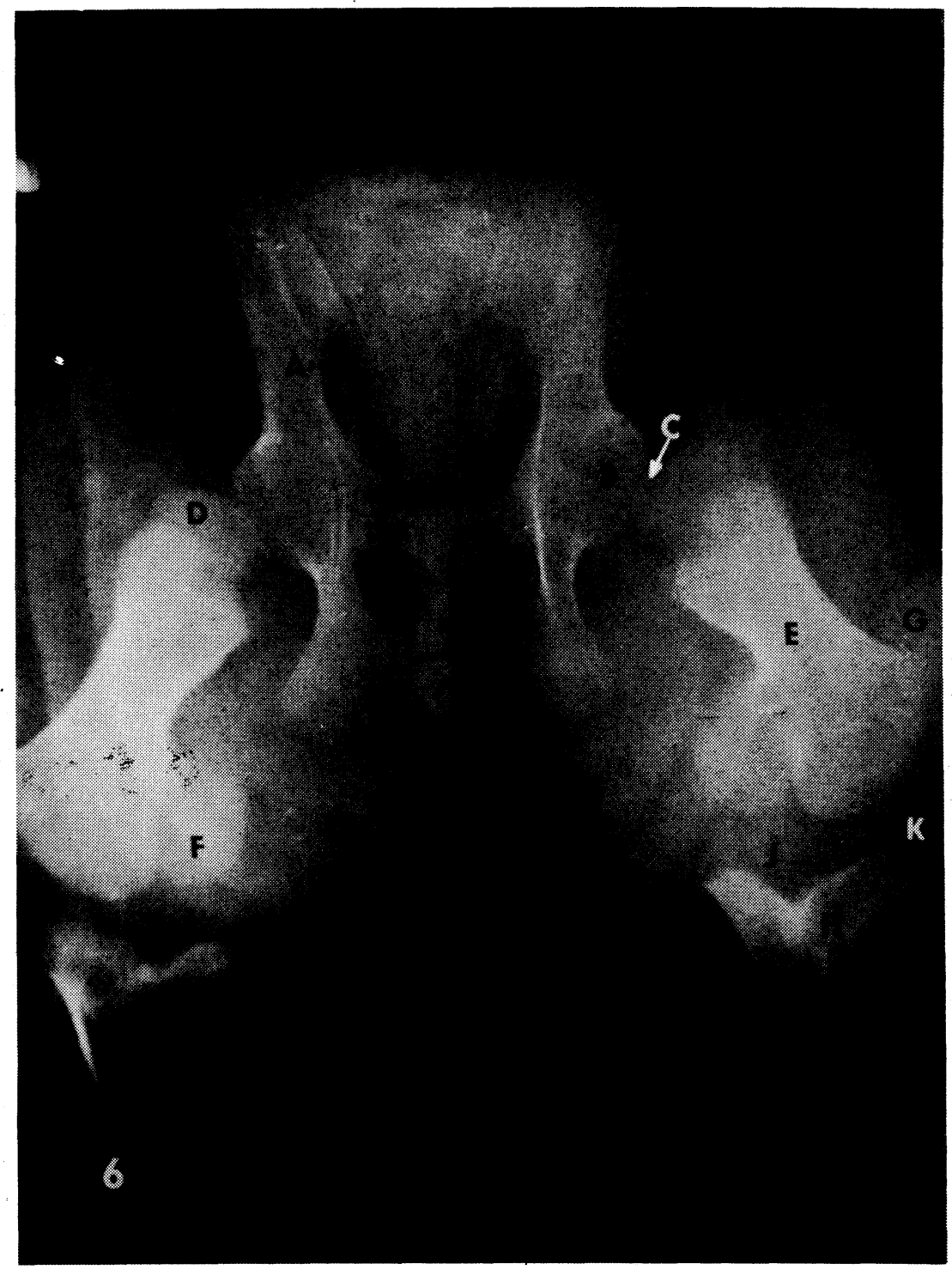

Fig. 6. Another alteration of findings in a CHDF pig with total collapse of motility. Ventrodorsal projection of pelvic region and thigh. All pelvic bones noticeably thicker, right half shorter, with the left ilium deviated laterally, spherical acetabulum as a result of time delays in growth cartilage closure.

A - deviated right, B - spherical acetabulum sinistrum, C - dysplastic bone tissue filling acetabulum and forming a copula-shaped protrusion above it, D - thinned and flattened caput femoris, E - extremely shortened diaphysis and enlarged epiphysis (F) ossis femoris dextri, $G$ - enlarged patella, H - cone-shaped epiphysis with concave articular surface, pressed into a funnel-shaped metaphysis, $\mathbf{J}-$ greatly thinned down cartilago epiphysialis, $\mathbf{K}-$ epiphysis proximalis fibulae extending over tibia, $L-$ shadows of skin folds. 


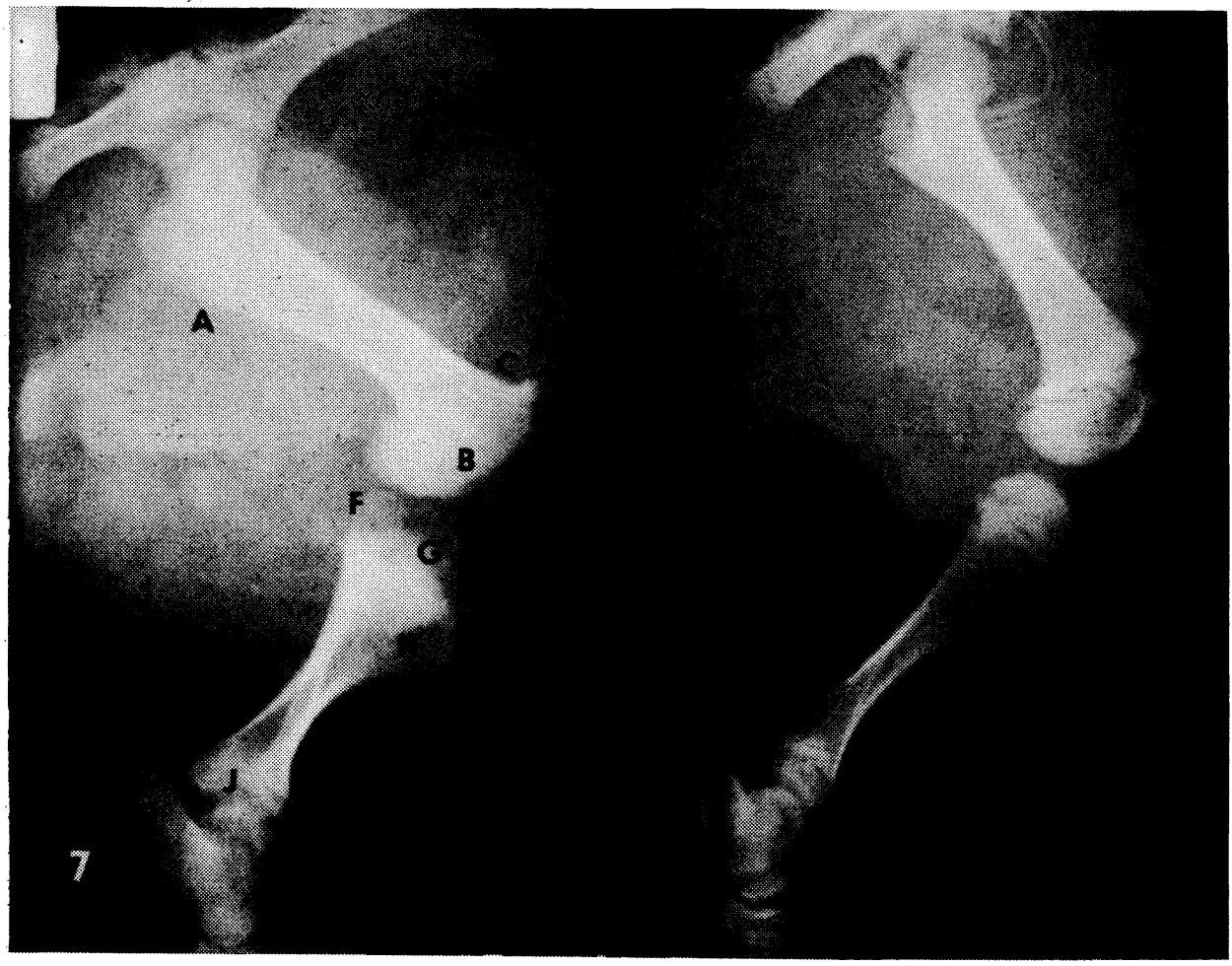

Fig. 7. Comparative radiograph of isolated pelvic limbs of a pig with a mild form CHDF and a control. Lateromedial projection. The most significant differences: clearly demonstrable brightening of epi- and apophyseal cartilage in the control has disappeared or become little discernible in CHDF, ossification generally more advanced; disproportions in the length and thickness of bones, size of epi- and apophyses, their localization and angles at which they meet. In the CHDF pig also relatively more extensive muscle development and skin folds.

A - still discernible cartilage apophysialis trochanteris majoris, B - flattened trochlea, C metaphysis rim bent into a gutter-like shape, D - patella, E - tuberositas tibiae, F - epiphysis proximalis fibulae, $\mathrm{G}$ - hypoplastic epiphysis proximalis tibiae, $\mathrm{H}$ - dilated metaphysis of the tibia, J - distal epiphysis of the tibia and dilated metaphysis grown together. 


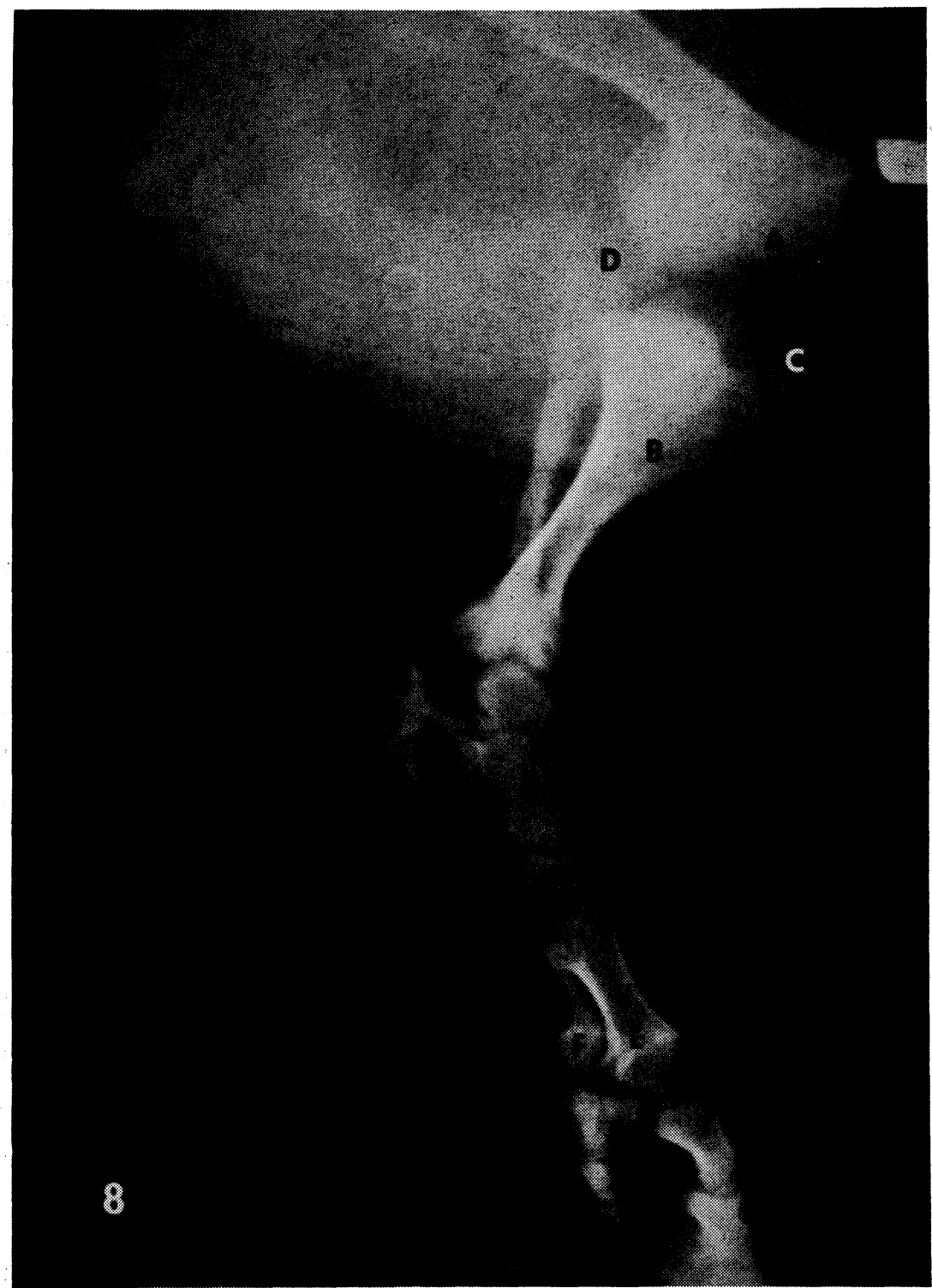

Fig. 8. Lateromedial radiograph of pelvic right limb with medium severe CHDF.

A - femur trochlea shifted distally, B - typical goblet shape of the tibia with heavily dysplastic proximal epiphysis, C - crista tibiae shifted proximally from its cranial position, D - proximal epiphysis of fibula extends markedly over tibia, angle at which they meet is wider, $\mathrm{E}$ - shortened, distally broadened principal metatarsus to club-like shape, $\mathrm{F}$ - drumstick broadening of distal meta- and epiphyses of the subsidiary metatarsus. 


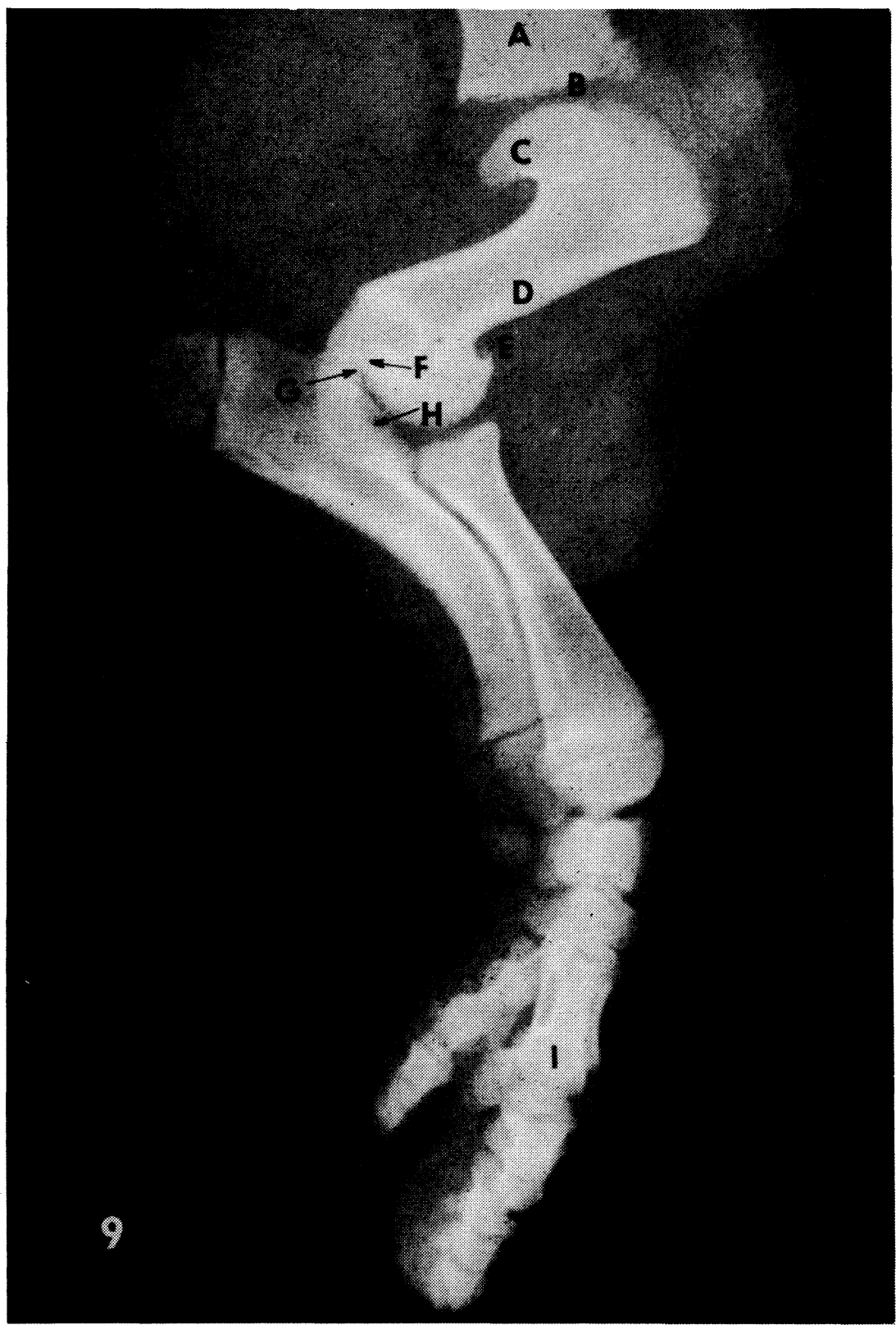

Fig. 9. Lateromedial rediograph of thoracic limb of a serious case of CHDF in a pig. The most characteristic symptom is thicker and markedly shorter femur and toadstool shape of its caput humeri. Bones are well mineralized, growth cartilage generally closed with the exception of ulna.

A - completely flat or even slightly convex cavitas glenoidalis, B - thicker collum scapulae, C - extended, strongly flattened and distally overhanging caput humeri, D - thicker corticalis, E - anomalous joint trochlea, extending above fossa radii of humerus, $F$ - joint trochlea extends into fossa olecrani, blocking it partially, with processus anconeus (G) hitting against it, $\mathrm{H}$ - extremely developed epicondylus medialis, I - club-shaped metacarpals. 


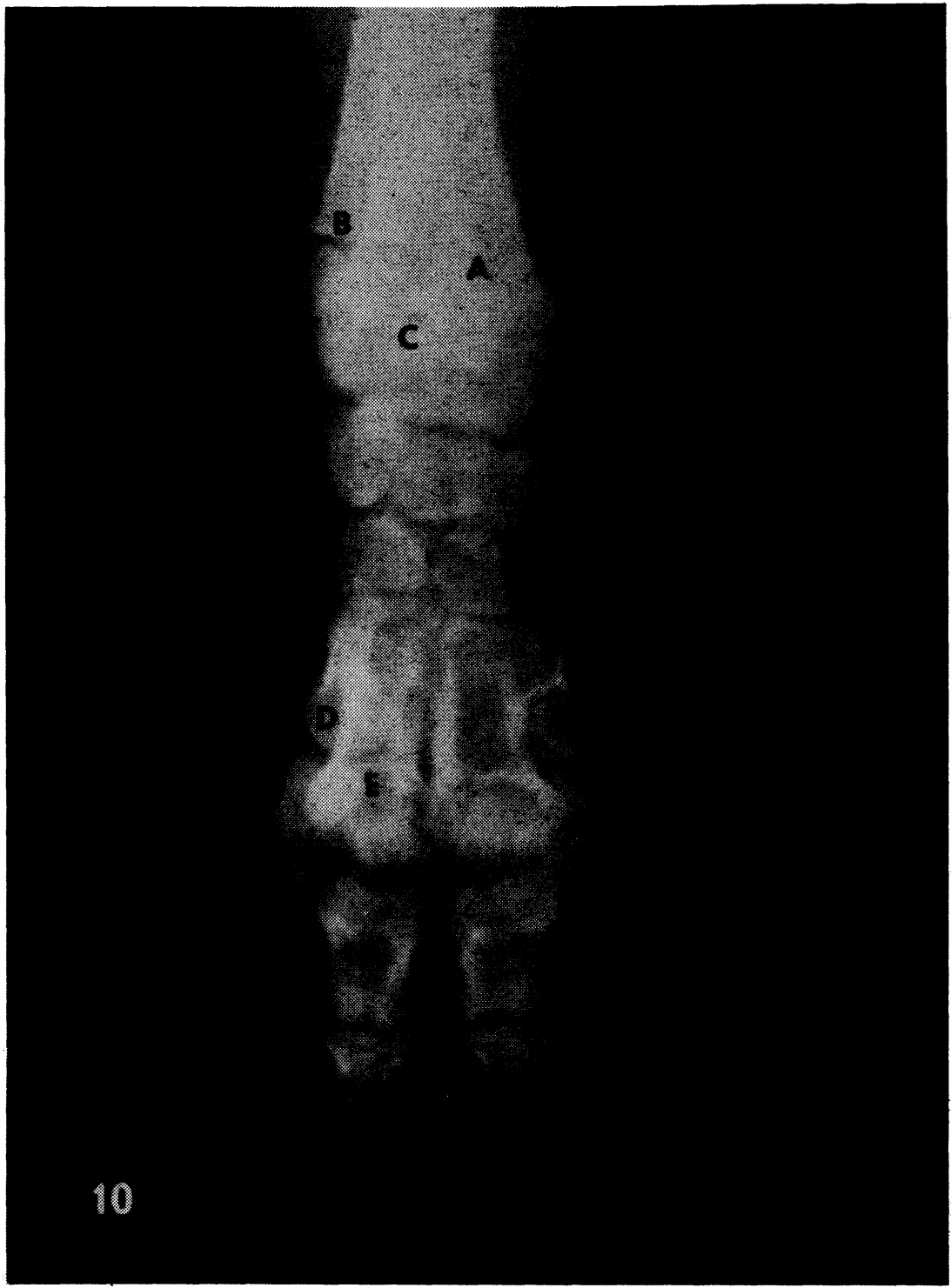

Fig. 10. Radiograph of autopodium of a thoracic limb of a pig, severe CHDF.

A - broadened distal metaphysis of the radius, its rim bent proximally in a gutter-like shape, B - brightening of distal epiphyseal cartilage of the ulna, C - distal epiphyseal cartilage of the radius greatly narrowed, in places ossified, medially preserved, D - shortened metacarpus $\mathrm{V}$ of characteristic drumstick shape, E - metacarpus IV, shortened, thicker, distally greatly broadened. 


\section{Rentgenologická studie chondrodysplasia fetalis prasat}

Pro rentgenologickou studii chondrodyplasia fetalis (CHDF) jsme měli k dispozici 6 prasat $\mathrm{o}$ hmotnosti $20-30 \mathrm{~kg}$ s rủzným stupněm poruch pohybu a stání, pocházejících $\mathrm{z}$ chovu s hromadným výskytem tohoto onemocnění, a dvě kontrolní zdravá zvírata obdobné hmotnosti. Mírný stupeň CHDF lze rentgenologicky obtižně diagnostikovat bez dostatečné praxe nebo srovnání s kontrolou. Těžší stupeň CHDF je natolik charakteristický, že by neměl být zaměňován za jiná onemocnění. Přesto některé útvary zobrazené na rentgenogramech bylo možné identifikovat až konfrontacís patologickoanatomickými a osteologickými preparáty $\mathrm{z}$ rentgenovaných zvif́at.

Celková mineralizace kostry se na rentgenogramech v podstatě nelišila od kontrol. Nejvýraznějším rysem CHDF je deformace a předčasný, různě rozsáhlý uzávěr epifyzámích rủstových chrupavek a zastavení enchondrálního typu růstu dlouhých kostí končetin. Zejména jsou zkráceny kosti pažní, stehenní, bércové a metapodiální. Epifýzy jsou silně zvětšené a deformované, což zpủsobuje těžkou inkongruenci kloubů s adekvátními poruchami motility. Časté jsou i těžké dysplazie kyčelních kloubů. Płredčasné časově rozdíné uzavíráni jednotlivých acetabulárních rủstových chrupavek má za následek nủznou asymetrii pánve. Na jiných než končetinových kostech jsme znaky CHDF neprokázali, a proto nemoc označujeme jako chondrodysplasia fetalis disproporcionalis.

Rentgenologie se osvědčila jako rychlá, jednoduchá a názorná metoda, umožnující především včasnou diagnostiku CHDF v době, kdy ji nelze ješť postihnout adspekcí či klinickým vyšetřením.

\section{Рентгеологические исследовапие хондродисплазии плоха свиней}

Для рентгенологического исследования хондродисплазии плода (ХДП) в нашем распоряжении находились 6 свиней массой 20-30 кг с разной степенью нарушения движения и стояния, происходящие из свиноводства с массовым наличием данного заболевания, и две контрольные здоровые свиньи той же массы. Небольшую ступень ХДП рентгенологически диагностировать трудно без наличия достаточной практики или сравнения с контрольной группой. Более тяжелая стадия ХДП настолько характера, что ее не следует заменять с другими заболеваниями. Несмотря на это, некоторые образования на рентгенограммах можно было идентифицировать лишь сопоставлением с патологоанатомическими и остеологическими препаратами просвечиваемых рентгеном животных.

Общая минералогизация скелета на рентгенӧраммах существенно не отличалась от контрольных животных. Самой выразительной чертой ХДП является деформация и преждевременное, разных масштабов закрытие эпифизарных хрящей роста и прекращение эндохондрального типа роста длинных костей конечностей. В особенности сокращаются плечевые, бедренные, берцовые и метапедиальные кости. Эпифизы существенно увеличенные и деформированные, что вызывает тяжелую инконгруентность суставов с соответствующими нарушениями моторики. Часто встречаются тяжелые досплазии тазобедренных суставов. Преж- 
девременное в разной последовательности закрытие ацетабулярных ростовых хрящей выливается в разную асимметрию таза. На других костях кроме конечностей признаки ХДП нами не были установлены и поэтому данное заболевание нами обозначается как chondrodysplasia fetalis disproporcionalis.

Рентгенология зарекомендовала себя в качестве оперативного, простого и наглядного метода, способствующего прежде всего своевременњому диагнозу ХДП в период, когда ее нельзя определить на глаз или клиническим исследование.

\section{References}

ALMLÖF, J.: On achondroplasia in the dog. Zbl. Vet. Med. 7, 1961: 43-56.

DÄMMRICH, K. Ein Beitrag zur Chondrodystrophia fetalis bei Tieren. Berl. Münch. tierärztl. Wschr. 80, 1967: 101-105.

DÄMMRICH, K: Entwicklungsstörungen des Skelets. In: JOEST, E. ed.: Handbuch der speziellen pathologischen Anatomie der Haustiere. IV, 3. Auflage, Berlin - Hamburg, 1985.

FLETCH, S. M. - M. E. SMART - P. W. PENNOCK - E. SUBDEN: Clinical and patholgic features of chondrodysplasia (dwarfism) in the Alaskan Malamute. J. Am. vet. Med. Ass. 162, 1973: 57-361.

HÁMORI, D.: Constitutional disorders and hereditary diseases in domestic animals. Akadémiai Kiadó, Budapest, 1983.

JENSEN, P. T. - NIELSEN, D. H. - JENSEN, P. - BILLE, N.: Hereditary dwarfism in pigs. Nord, Vet. Med., 36, 1984: 32-37.

JUBB, K. V. F. - KENNEDY, P. C. - PALMER, N.: Pathology of domestic animals. Vol. 1, Third edition. Academic Press, Inc., Orlando, Florida, 1985.

KAMAN, J. - DRÁBEK, J. - ŽERT, Z.: Výskyt chondrodysplasia fetalis u prasat. Veterinářství, 37, 1987: 10, 443-446.

MATHER G. W.: Achondroplasia in a litter of pups. J. Am. vet. Med. Ass., 128, 1956: 327-328.

NACHTSHEIM, H.: Erbpathologie des Stützgewebes der Säugetire. In: JUST, G. ed.: Handbuch der Erbpathologie des Menschen. Bd 3/1, Springer Verlag, Berlin, 1940.

NIEBERLE, K - COHRS, P.: Lehrbuch der speziellen pathologischen Anatomie der Haustiere. T. II, Fünfte Aufgabe. VEB G. Fischer Verlag, Jena, 1970.

SZEMES, A. L.: Epiphysen und Apophysen in der röntgenologischen Darstellung an der Vorder-und Hinterextremitäten des Schweines. Inaug. Diss. Vet. Med., Tierärztliche Hochschule, Hannover, $1962,32 \mathrm{p}$.

SUBDEN, R. E. - FLETCH, S. M. - SMART, M. A. - BROWN, R. G.: Genetics of the Alaskan Malamute chondrodyplasia syndrome. J. Heredity, 63, 1972: 149-152.

WEISS, R: Röntgenologische Feststellung des Epi- und Apophysenfugenschlusses beim Schwein. Diss. Vet. Med., Tierärztliche Hochschule, Hannover, 1972, 67 p.

WRATHALL, A. E. - BAILEY, J. - HEBERT, C. N.: A radiographic study of the appendicular skeleton in the fetal pig. Res. vet. Sci. 17, 1974: 154-168.

WRAY, C. - MATHIESON, A. O. - COPLAND, A. N.: An achondroplastic syndrome in South Country Cheviot sheep. Vet. Rec., 88, 1971 : 521-522. 